\title{
GENERAL CHARACTERIZATION OF SECURITY SYSTEMS FOR OBJECTIVES, GOODS, VALUABLES AND PROTECTION OF INDIVIDUALS \\ F. Mateaş
}

\author{
Florian Mateaş \\ Law and Economics Faculty, Social Sciences Department \\ Agora University of Oradea, Oradea, Romania \\ *Correspondence: Florian Mateaş, Agora University of Oradea, 8 Piaţa Tineretului St., \\ Oradea, Romania \\ E- mail: departament@univagora.ro
}

\begin{abstract}
The local police operate as a public institution with legal personality for the interest of citizens, which provides services for the security of goods, participates in the defence of public order and peace, of the life and integrity of individuals, and other rights and legitimate interests of the community.

The organization and carrying out of the guarding of the goods and valuables of any kind owned, their transportation and other security services, and participation in the defence of public order and peace are done on the basis of contracts concluded between the local Police and mayors, public or private economic operators, institutions, associations of any kind, natural or legal persons as appropriate.

The security provided by local police officers is carried out according to the security plan drawn up by local police commanders and beneficiaries, approved by the local committee and with the expert's approval from the local police. In their work for performing the service at the objectives entrusted to them, the local police officers have a number of obligations including cooperation with the police bodies and the notification thereof when finding crimes committed which might damage public and private property, acts directed against individuals, fire occurrence, calamities.
\end{abstract}

Keywords: security systems, security of objectives, protection of individuals, missions, security, national security, local police.

\section{Introduction}

The local police and other structures specialized in guarding objectives, goods, valuables and providing imdividulas' protection, have this mission which becomes, as criminals change their methods, an interesting scientific approach focusing on new developments at global and regional level, which result in new dimensions of national security and safety.

People have always tried to ensure their protection against certain eventualities, first by satisfying their vital needs and later by giving rise to bodies empowered to ensure the existence of this national security and/or international security. protection

1. Security systems for objectives, goods, valuables and individual 
I have felt the need to order, systematize and group knowledge regarding each topic discussed, because a large number of controversies and theories have emerged from the study of a vast documentary material, which only make it possible to develop my own conclusions after some preliminary clarifications ${ }^{1}$.

Security went from being defined as "a state of facts" that alters its composition with the developments of technique and technology and in parallel with terrorist attacks and organized crime, to representing a security environment. The security issue has preoccupied human communities throughout their existence. In effect, the provision of community security has emerged with the social-political organization of human society. The concept of security on the individual level expresses the feeling of being out of danger, of being protected in order to live in peace in an environment that allows selfassertion on multiple levels. On the collective level, the concept of security means the situation where, following specific measures of protection, a group of people, a state or groups of states have the certainty that their existence, integrity or fundamental interests are protected.

Security ensures the well-being, the protection of the individual, as well as everything related to the human individual: nutrition, economics, education, environment, etc. The fight against terrorism, as a manner of ensuring mankind security, "should take account of compliance with human rights". All modern human communities have come to understand the need to intensify efforts to appease conflicts in their inception phase. Therefore, the attention of decision-makers and analysts in each country are turning more and more to those events, processes and phenomena that might give rise to dangerous contradictions, trying to discover, examine, master them, keeping them constantly under control.

Depending on the importance, specific nature and value of the goods they hold, managers of units, with the specialized support of the police for civil security systems or of the gendarmerie for military security systems, will estalish concrete ways of organizing and performing guarding services, as the case may be, with gendarmerie manpower, with local police officers, own security guards or specialized security companies.

The law clearly establishes the role and duties of the Ministry of Administration and Interior which, in their vast majority, are carried out by police units.

According to Art. 26 point 5 of the Local Police Law no. 155 of $12^{\text {th }}$ July 2010 on the organization and functioning of the local police, this institution regulates and controls, under the law, the setting up of private detective, security, surveillance and bodyguard companies.

Through the public order patrols, the police have sole jurisdiction to adjudicate on the quality and efficiency of any security system, excluding the military guard organized and carried out by gendarmes at the objectives where the latter provide security services.

The concern for improving the work style of the Local Police will certainly acquire a special intensity in the future. Today, managerial science offers a wide range of management tools and models in order to achieve managerial performance. In police

\footnotetext{
1 Voicu C, Sandu F, Management Organizaţional în Domeniul Ordinii Publice (Organizational Management in Public Order), vol. II, Editura Ministerului de Interne (Ministry of Interior Publishing House), Bucharest, 2009, p. 37.
} 


\section{GENERAL CHARACTERIZATION OF SECURITY SYSTEMS FOR OBJECTIVES, GOODS, VALUABLES AND PROTECTION OF INDIVIDUALS}

work, especially in the context of European integration, managerial performance is inextricably connected to improving the work style of managers.

As for the rest, all those who organize and carry out the other forms of security guard through community police officers, security through specialized companies or bodies, or their own security guards, are required to obtain the specialized technical approval of the police and to comply with the instructions, guidelines and measures ordered by the police.

\section{The notion of security of objectives, goods and valuables and protection of individuals}

Romanian Police are part of the Ministry of Interior and are the specialized institution of the State which exercises powers regarding the defence of the fundamental rights and freedoms of individuals, of private and public property, the prevention and detection of crimes, respect for public order and peace, under the law.

The activity of the Romanian Police is a specialized public service done in the interest of the individual, the community, as well as in support of State institutions, exclusively on the basis of and in compliance with the law.

In carrying out their missions, the Romanian Police cooperate with State institutions and collaborate with non-governmental associations and organizations, as well as natural and legal persons, within the limits of the law².

Security and protection are activities which deal with the main operational management methods used by an effective manager of a local police unit - plan-based management, budget-based management, project-based management, system-based management, management by results, management through product, management by exception, objective-based management, participative management, object-based management, management through cooperation and collaboration, management by delegation, management by motivation, management by innovation, management by information and communication, management by alternative, management by consent ${ }^{3}$.

On the basis of this methodology, security and protection structures comprise:

a) specialized security and protection companies; Decision;

b) specialized bodies organized by regulations approved by Government

c) own security guards ${ }^{4}$.

All these approaches have allowed revealing some new elements and theoretical and pragmatic personal contributions, this work being aimed at highlighting the weaknesses of the current system in theoretical terms and finding pragmatic solutions in order to minimize them. The research concept kept in mind takes as a starting point the idea that only Local Police tasks can provide solutions to the existing problems in order

\footnotetext{
${ }^{2}$ Law no. 218/2002 on the organization and functioning of the Romanian Police.

${ }^{3}$ Team of authors, coordinators Frunzeti Teodor, Zodian Vladimir, Lumea 2010, Enciclopedie politică şi militară, studii strategice şi de securitate (Political and Military Encyclopedia, Strategic and Security Studies), Editura Centrului Tehnic-Editorial al Armatei (Technical Editorial Army Centre Publishing House), Bucharest, 2011, p. 129.

${ }^{4}$ Romanian Police General Inspectorate (RPGI/IGPR) Order no. 422/25 ${ }^{\text {th }}$ September 2006 on the regulation of the work performed by police structures in the field of security of objectives, goods, valuables and protection of individuals, Art. 1, para. 2.
} 
to achieve performances of the management team. Therefore, I intended this work to deal with some problems that are new to the field, such as:

- highlighting the main managerial aspects of the strategy in conjunction with an effective work style in ensuring public order in the contemporary society;

- managerial concerns for implementing an active, participative work style of managers within the Local Police; a conceptualization of the work style term;

- managerial involvement in the improvement of the work style in the Local Police;

- pragmatization of the work style of the Local Police managers;

- management approach in the activity for combating crime, through conceptual research and concrete practical actions;

- identification and analysis of the essential characteristics of a well-performing management in the police sector;

- dealing with conditions, criteria and processes in their complexity, which is necessary in order to improve the work style and methods of managers in relation to subordinates, etc.

- facilitating the understanding of the purpose of the activity carried out by the police by all natural and legal persons, the understanding of the need to promote and extend modern management methods and techniques in the Local Police, etc.

- managerial involvement in the improvement of the work style within the Local Police.

The responsibility for coordinating and guiding the activity carried out by the security and protection structures mentioned, for the prevention and fight against crimes, against other violations of the law in this area, lies with the Public Order Police Directorate of the Romanian Police General Inspectorate and with the Public Order Police Services of the County Police Inspectorates, respectively the General Police Directorate of Bucharest Municipality, according to jurisdiction.

For objectives or activities organized in the field of rail, marine and air transport, the jurisdiction belongs to the Transport Police Directorate, Regional Transport Police Departments, County Services and Transport Police Stations.

At the level of the Public Order Police Directorate and Transport Police Directorate, a specialized service operates, organized by departments and lines of work. Within the Public Order Police Services of the County Police Inspectorates, operates the Security System Department consisting of officers, of which at least one is an electronics specialist who isin charge of the control, support and guidance of the work carried out by the security and protection structures, the beneficiaries of these services, as well as the monitoring of the activities of the subordinate police structures.

At the General Police Directorate of Bucharest Municipality, in the Public Order Police Service, a Security System Office operates. Within the public order structures, one or more police officers will be appointed, depending on the volume of activity by field, who should be in charge of the issue of security, assessed according to specific indicators.

In rural areas, guard security activities are carried out by officers and agents within Communal Police Offices or Stations, in the assessment of which specific indicators shall be taken into account ${ }^{5}$.

5 Cearapin Tudor, Managementul resurselor umane în domeniul ordinii publice (Human Resources 


\section{GENERAL CHARACTERIZATION OF SECURITY SYSTEMS FOR OBJECTIVES, GOODS, VALUABLES AND PROTECTION OF INDIVIDUALS}

In order to combat crimes aimed at the property of institutions or economic entities, police officers in the Security System Departments carry out informativeoperational activities to identify those who violate legislation in the field of security and protection of objectives, goods, valuables and individuals, by ordering legal measures ${ }^{6}$.

The most dangerous crisis situations likely to cause serious disturbances of public order would be the following: separatist actions; diversionary-terrorist actions; sabotages; blocking of civilian or military objectives, of land, water, rail transport and communication of strategic importance, of the national energy system; actions meant to destabilize the rule of law. The internal forces that may undertake hostile and aggressive actions touching upon national security are: ethnic groups, infiltrated groups or groups formed on the Romanian territory, research and diversion elements, groups formed on religious grounds; terrorist, terrorist-diversionary groups or elements; paramilitary units made up of runaways, exiles, immigrants and mercenaries specially trained on the national territory or abroad, groups of foreigners having come as tourists, meant to prepare, train and possibly lead the structures of separatist forces; internal dissident elements, making up legal organizations and controlled from the exterior; internal elements in conflict with the law and without occupation, hired with wages, political parties and legal organizations engaged in setting up a non-constitutional regime. Alos, risk situations have emerged, with the potential to disturb public order, which could degenerate into serious disturbances of public order, touching upon state security?

Lately, new concepts have emerged in the specialized literature, such as management of crisis situations, indicating a constant concern for uniting efforts in order to eliminate conflicts regardless of their type, a complex and documentary approach of the situations that generate them, with particular emphasis on concrete ways to solve a crisis ${ }^{8}$.

Regarding the ways of making decisions in crisis situations, a few highlights are necessary:

- a crisis is characterized, among other things, by the way in which a State initiates it and the way in which another State responds to it and takes decisions;

- the number of decision-makers is an interesting landmark. In a serious crisis entailing a risk of war, the responsibility to pursue the situation and propose measures to be taken to the supreme commander lies with a very small group of people, of a high hierarchical rank;

- rigorously selected members of such a group easily communicate with each other. A quick and consensual choice of actions to be undertaken is therefore possible, in principle. The problem posed by extremely tight deadlines is thus better surpassed than by adopting a more complex structure;

Management in Public Order), Editura Universitas (Publishing House), Bucharest, 2006, p. 153.

${ }^{6}$ Appendix to the Romanian Police General Inspectorate (RPGI/IGPR) Order no. $7 / 7^{\text {th }}$ February 2008 on the concept of organization and action of public order police structures, Art. 21.

${ }^{7}$ Law no. 333/8 $8^{\text {th }}$ July 2003 on the security of objectives, goods, valuables and individuals, Art. 5.

${ }^{8}$ Law no. 333/8 th July 2003 on the security of objectives, goods, valuables and protection of individuals also provides, in Art. 3 para. (4), that: "the protection of Romanian and foreign dignitaries during their stay in Romania, of their families, the security of their work offices and residences shall be ensured by the Protection and Guard Service according to its duties set out by the special law on its organization and operation." 
- conversely, during prolonged crises of low intensity, entailing fewer serious risks and more time to deal with them, the implementation of decisions becomes increasingly administrative in nature. The more people are involved and the greater the flow of information processed, the harder it is to achieve consensus;

- unitary crisis assessment by states is a recent phenomenon. Of course, before 1945, in the absence of modern means of information, communication and rapid processing of data, there were no ad-hoc structures able to help the heads of state in crisis management. It was only as late as the year 1962 that institutionalized structures enabling decision-making were set up as attached to the great powers. To mitigate risks arising from very short deadlines, from very strong pressure, from excessive fatigue, countless "crisis cells" gradually appeared, increasingly better equipped, both within states and within the large national or multinational enterprises.

The diagnostic analysis revealed essential aspects that we present below.

The main positive aspects signaled are:

a) general:

- the functional structures' ability to adapt to the changes and requirements of the socio-economic environment and to the national objectives imposed by the European integration and by membership to the North-Atlantic Treaty Organization - NATO;

- the development and promotion of regulatory acts in accordance with European Union standards and the Acquis Communautaire;

b) in the field of Public Order and Safety

- organized and disciplined working environment;

- numerous opportunities for professional training and improvement.

The main weaknesses are:

a) general:

- internal communication difficulties which generate a certain resistance to change;

- insufficient coherence in adopting sub-sectoral policies and strategies;

b) in the field of Public Order and Safety

- a shortage of staff within the operational structures, which decreases the capacity for action of public order structures;

- the delay in implementing some of the reform measures set out;

- the delay in adopting and using as equipment modern methods and means for real-time crisis management;

- the lack of criminal risk assessments in local communities;

- malfunctions in providing material and financial resources.

As part of the specific activities they carry out within their competence area, local police officers will identify the objectives that require the setting up of physical guarding, the implementation of mechanical and electronic security systems ${ }^{9}$ or the upgrade and supplementing thereof, as well as their connection to local monitoring control rooms, notifying about this, on the basis of a grid, the Security System Departments of municipal and city police units. Police officers in these departments will check and order legal measures to secure the objectives signaled.

\footnotetext{
${ }_{9}^{9}$ Armstrong M, Baron A, (2014),Managing Performance. Performance management in action Hargie, O. \& Tourish, D. (2009) Auditing Organizational Communication. New York: Taylor\&Francis.
} 


\section{GENERAL CHARACTERIZATION OF SECURITY SYSTEMS FOR OBJECTIVES, GOODS, VALUABLES AND PROTECTION OF INDIVIDUALS}

Owners' associations will be advised by local police officers to take measures for the implementation of appropriate electronic and mechanical systems at the entrances of block staircases. Also, recommendations will be made, in areas where this is required (parking lots, isolated walkways, places where public order is frequently violated or neighbourhood gangs are active, etc.), in order to have security and protection systems organized by licensed companies as patrol systems ${ }^{10}$.

\section{Specific documents required for the implementation and records of the security service}

These documents and records must be present in all units equipped with any of the forms of security provided by the law becuase they are indispensable to the conduct of the security activity, as they keep track of all the activities and operations carried out by the security personnel and of the control activities the object of which are such activities.

The managerial decisions that operationalize the personnel recruitment strategies and policies should consider the following issues:

- identifying and attracting a number of candidates as large as possible in order to obtain the necessary number and quality of employees;

- the extent to which vacant places are filled up from within the organization, from among its own employees, from outside the Ministry of Administration and the Ministry of Interior, or by combining these two possibilities;

- ensuring consistency between the recruitment activities of the Ministry of Interior and the values and strategies thereof;

- the extent to which the Ministry of Administration and the Ministry of Interior prefer to attract satisfactorily-qualified candidates who are looking for a job and are interested in quickly occupying vacant jobs, or try to attract competitive candidates who have a real interest in vacant jobs, who are prone to a long-term career and can ensure an efficient management in the field of human resources;

- the concern of the Ministry of Administration and the Ministry of Interior with identifying and attracting a variety of categories of candidates;

- taking account of the objectives envisaged after hiring the personnel, including post- recruitment effects;

- personnel recruitment efforts should lead to the expected effects, including the improvement of the overall image of the Ministry of Administration and Interior, so that even rejected candidates might develop positive images or attitudes towards the organization, that they might further communicate;

- carrying out personnel recruitment within a period of time as short as possible and with the lowest possible costs;

- appointment of special working groups in order to broaden professional skills;

- participation in training activities: symposia, seminars, distance learning, etc. ${ }^{11}$.

10 Romanian Police General Inspectorate (RPGI/IGPR) Order no. 422/25 th September 2006 on the regulation of the work performed by police structures in the field of security of objectives, goods, valuables and protection of individuals, Art. 81.

${ }^{11}$ Government Decision no. 1010/10 th August 2004 approving the rules laid down in Art. 69 of Law no. $333 / 2003$ on the security of objectives, goods, valuables and protection of individuals, Appendix 4, Art. 1. 


\section{Conclusion}

The control of security activity is not only about how the security personnel fulfill their duties, it concerns the entire way in which those units comply with the legal provisions regarding the security of objectives, goods or valuables ${ }^{12}$.

The primary goal is to prevent and detect thefts from the objective under security guarding, performing for that purpose checks at access points, stalks and operational surveillances.

The findings made on the occasion of the inspections shall be recorded in the single control register of the unit, measures and tasks being put into place in order to eliminate the shortcomings discovered, the deadlines being achieved by the unit chief.

According to Law 333/2003, the security personnel is assimilated, during the performance of the guarding, to the official who performs a duty involving the exercise of state authority, thus being achieved the legal protection of security personnel, which, at the same time, can be held accountable in relation to offences they commit while in office.

\section{Bibliography}

1. Local Police Law no. 155 of $12^{\text {th }}$ July 2010 ;

2. Government Decision no. 1332/2010;

Order no. 92 of $5^{\text {th }}$ May 2011 approving the Methodology for approving the plan of public order and safety of the Local Police;

3. Jackson M. Peter, Palmer (2003) "Public Service Performance Evaluation: A Strategic Perspective";

4. Coşcodaru Ion (coordinator), Doctrina Armatei României (Romanian Army Doctrine) (project), Bucharest, 2014;

Androniceanu, A, (2004), Noutăţi în managementul public (New Public Management), Editura Universitara (University Publishing House), Bucharest;

5. Cearapin Tudor, Managementul resurselor umane în domeniul ordinii publice (Human Resources Management in Public Order), Editura Universitas (Publishing House), Bucharest, 2006;

6. Voicu C., Sandu F (2009), Management Organizaţional în Domeniul Ordinii Publice (Organizational Management in Public Order), vol. II, Editura Ministerului de Interne (Publishing House of the Ministry of Interior), Bucharest;

7. Armstrong M, Baron A, (2004), Managing Performance. Performance management in action Hargie, O. \& Tourish, D. (2009) Auditing Organizational Communication. New York: Taylor\&Francis

8. Patrick von Maravic (2007), Reforma managementului public şi corupţia conceptualizarea consecinţelor neintenţionate (Public Management Reform and Corruption - Conceptualization of Unintended Consequences), journal Administraţie şi Management Public (Public Administration and Management), issue no. 8;

12 Iordan Nicola (2008), Managementul serviciilor publice locale (The Management of Local Public Services), Editura All Beck (Publishing House), J. Maciariello - The Daily Drucker, Elsevier, Butterworth Heinemann, UK, 2009 Jablin, F \& Putnam L, (2001) The New Handbook of Organizational Communication, available on-line at www.books.google.com 
9. Iordan Nicola (2008), Managementul serviciilor publice locale (Management of Local Public Services), Editura All Beck (Publishing House) J. Maciariello - The Daily Drucker, Elsevier, Butterworth Heinemann, UK, 2009 Jablin, F \& Putnam L., (2011) The New Handbook of Organizational Communication, available on-line at www.books.google.com 10. Team of authors, coordinators Frunzeti Teodor, Zodian Vladimir, Lumea 2010, Enciclopedie politică şi militară, studii strategice şi de securitate (Political and Military Encyclopedia, Strategic and Security Studies), Editura Centrului Tehnic-Editorial al Armatei (Technical Editorial Army Centre Publishing House), Bucharest, 2011; 11. Armstrong M, Baron A, (2014), Managing Performance. Performance management in action Hargie, O. \& Tourish, D. (2009) Auditing Organizational Communication. New York: Taylor\&Francis. 